\title{
Agronomic Use of Sewage Sludge in Degraded Area Recovery: Pilot Study to Produce Native Tree Species
}

\author{
Amanda Cerqueira Carvalho ${ }^{1}$, Danielle Salomão Ribeiro ${ }^{1}$ and Rodrigo de Freitas Bueno ${ }^{2 *}$ \\ ${ }^{1}$ Department of Environmental Engineer, University Oswaldo Cruz- FOC, Brazil \\ ${ }^{2}$ Central of Engineering, Modelling and Applied Social Sciences of the Federal University of ABC, Brazil
}

Submission: December 18, 2017; Published: January 24, 2018

"Corresponding author: Rodrigo de Freitas Bueno, Central of Engineering, Modelling and Applied Social Sciences of the Federal University of ABC, Av. dos Estados, 5.001, 09210-580, Santo André - SP, Brasil, Email: rodrigo.bueno@ufabc.edu.br

\begin{abstract}
The increase of the world population has led to the growth of land use and its inadequate management has been responsible for the high number of degraded areas. Therefore, the present work had as objective to evaluate treatments with alternative substrate, the sewage sludge, its performance and viability in the production of seedlings. Moreover, the sewage sludge in different proportions was tested with five species selected according to the criteria of a resolution of Environment State Department of São Paulo. The species selected were: Schinus terebinthifolia, Samanea tubulosa, Erythrina speciosa, Caesalpinia peltophoroides and Psidium guajava. The treatments were: T0: 100\% substrate, T1: 20\% sludge and $80 \%$ substrate, T2: $40 \%$ sludge and $60 \%$ substrate and T3: $60 \%$ sludge and $40 \%$ substrate. In addition, the species in each treatment were evaluated at 30, 60 and 100 days, observing the phytometric parameters: Root length (CR), stalk length (CPA), dry root weight (MSR) and dry stalk weight (MSPA). This evaluation allowed to observe that the phytometric parameters of the seedlings of Caesalpinia peltophoroides that didn't differ statistically among treatments, responding well to all. Seedlings of the Erythrina speciosa species developed better in T3, while those of Samanea tubulosa had the highest values in T2. Schinus terebinthifolia seedlings responded better to the use of $100 \%$ substrate and Psidium guajava to the treatment with $20 \%$ of the volume of sludge and $80 \%$ of the substrate (T1). The seedlings will be donated to the Paraiba Valley Ecological Corridor, establishing biodiversity for the reforestation of degraded areas.
\end{abstract}

Keywords: Sewage sludge; Ecological corridor; Forest recovery; Degraded areas

\section{Introduction}

Environmental effects to be considered negative or adverse and resulting mainly from human activities or interventions, guarantee the concept of degradation. In turn, this rarely applies to change arising from natural phenomena or processes. Considering the growing need for recovery/restoration of areas already degraded or in the process of degradation by the exploitation of resources, methods are increasingly sought for recovery or reduction of impacts. The ecological corridors are forest restoration systems, carried out in strategic ways, which seek out places of interest so that reforest fulfill their function of maintaining natural resources and biodiversity. It is through the so-called connectivity lines that form ecological corridors with a high degree of interconnection, where organisms can move between the elements of the landscape, providing a great biological flow between the remnants of natural vegetation and allowing the maintenance of high diversity and reducing the risk of extinctions.

Therefore, the use of sewage sludge was considered as an alternative to produce native tree species, since the final disposal of the same has been shown as an environmental challenge, since the current practices adopted, besides costly, constitute as a focus of public health problems, because sewage sludge has a high organic load, contaminating water and contributing to the proliferation of disease vectors $[1,2]$. It is essential to realize studies on the use of sewage sludge to seek an alternative to the disposal methods currently adopted. A promising and feasible alternative is the use of sewage sludge as a fertilizer, in addition to presenting economic advantages, the same improvement of the soil physical conditions [3-5].

Within this context, the present work is based on verifying the feasibility of different dosages of sewage sludge in the growth of the species. To take advantage of the seedlings produced, they were donated to the Paraiba Valley Ecological Corridor project as an aid in the recovery of degraded areas and provide sustainable ways to maintain biodiversity. The root length (CR), stalk length (CPA), dry root weight (MSR) and dry stalk weight (MSPA) was evaluated in 30, 60 and 100 days, to verify the viability in the production of seedlings of native tree species. 


\section{Materials and Methods}

The experiment was conducted in mini greenhouses, installed at Oswaldo Cruz College (São Paulo, Brazil), which was made with metal structure, varnished wood base and covered with transparent polyethylene film, occupying an area of 60 centimeters wide by 90 centimeters long. The root trainers were glass bottles, which were adapted to receive the substrate studied.

According to Cunha et al. [6] the success rate of reforestation projects depends directly on the correct choice of species to be used. In these circumstances, with the objective of recovering degraded areas, the suggestion is that native species of seedlings adapted to the environment to be reclaimed are used, and the quality of the seedlings is an important element for the project to be successful, since interfere with the initial development of the capacity of the environment and future growth of the same, which is closely linked to the performance of the forest [7].

Tree species usually indicated for the recovery of degraded areas and for urban affore station were used in these study and the seeds were donated by the Harry Bloss feld Municipal Seedling Nursery, located inside the CEMUCAM Park, belonging to the State of São Paulo, Brazil. These had homogeneous characteristics and vigor. The species were: Schinus terebinthifolia (Brazilian pepper), Samanea tubulosa (Seven shells), Erythrina speciosa (Erythrina), Caesalpinia peltophoroides (False brazil wood) and Psidium guajava L. (Guava). These seeds of native forest species were planted in glass bottles used as root trainers, arranged inside the mini greenhouse.

The compounds used were made by mixing the substrate with different dosages of sewage sludge from a domestic sewage treatment plant under concession from the São Paulo State Basic Sanitation Company (SABESP, Brazil), which received the following treatments with five replicates each: T0: $100 \%$ substrate, T1: $20 \%$ sludge+ $80 \%$ substrate, $\mathrm{T} 2: 40 \%$ sludge $+60 \%$ substrate, and T3: $60 \%$ sludge and $40 \%$ substrate. The quantification of sewage sludge was based on similar studies.

The sludge undergoes a hygienisation process before being mixed with the substrate. The limestone was mixed to the sewage sludge when it reached the $40 \%$ solids percentage and the amount used was $50 \%$ of the dry sewage sludge weight [8]. Thus, for approximately $4.2 \mathrm{~kg}$ of sludge, about $2 \mathrm{~kg}$ of $\mathrm{CaO}$ were used. The $\mathrm{pH}$ was around 12 , generating an alkaline environment that acts to prevent the development of microorganisms. The chemical characterization of the substrate, sewage sludge and mineral fertilizer are contemplated in Table 1.

Table 1: Chemical characterization of the substrate, sewage sludge and mineral fertilizer.

\begin{tabular}{|c|c|c|c|c|c|}
\hline Parameters & $\begin{array}{c}\text { Potassium } \\
\left(\mathbf{K}_{\mathbf{2}} \mathbf{0}\right)\end{array}$ & Limestone & Nitrogen (Urea) & Phosphor $\left(\mathbf{P}_{\mathbf{2}} \mathbf{O}_{5}\right)$ & Sulfur (S) \\
\hline & $\%$ & $\%$ & $\%$ & $\%$ & 0.7 \\
\hline Sewage Sludge & 0.4 & 8.3 & 1.2 & 1.0 & 0.8 \\
\hline Substrate & 0.1 & 2.6 & 0.6 & $14(\mathrm{~b})$ & 5 \\
\hline Mineral Fertilizerc & $8(\mathrm{a})$ & 8.5 & 4 & $\%$ \\
\hline
\end{tabular}

Wherein: $\mathrm{a}: \mathrm{K}_{2} \mathrm{O}$ water soluble; b: $\mathrm{P}_{2} \mathrm{O}_{5}$ water soluble; c: Mineral Fertilizer is in the Table only for Comparison Purposes

After the preparation of the substrate and biosolids, the seeds of Erythrina and False brazilwood were scarified and soon after sown together with the other species. The seeds of Brazilian pepper and Guava went through soaking for 24 hours to break dormancy. It was used a manual sprinkler irrigation system, three times a day, for seed germination. The seedlings were followed for a period of 240 days, from November 2015 to July 2016. This period was considered adequate for the observation of the seedlings in the initial phase of growth.

\section{Data collection and analysis}

The analyzes of the seedlings were done according to the method described by Bortolini [9], where after the installation of the experiment, the height of the stalk and the root were measured at 30, 60 and 100 days. A millimeter steel ruler (with a total length of 100 centimeters) was used, making it possible to obtain a measurement with a significant number. For each measurement were selected 3 seedlings of each species (Brazilian pepper, Seven shells, Erythrina, False brazilwood and Guava) with the 4 treatments (T0, T1, T2 and T3).
One hundred days after the start of the experiment, the material was collected separately to determine the dry biomass. The seedlings were removed from the root trainers, washed with deionized water to remove the excess substrate from the root. After washing, the seedlings were cut at the height of the lap to separate stalk and root. These two parts were dried in the oven at $60^{\circ} \mathrm{C}$ at the Oswaldo Cruz Colleges Laboratory. Subsequently, the material was weighed in a precision electronic scale and the dry biomass weight data were recorded.

The data, after the collection, were analyzed for their variance by the ANOVA (Variance Analysis) method. After checking the differences between the treatments, they were compared through the Tukey test, at 5\%. For statistical calculations, the R Program for Statistical Computing program was made available for download on the ESALQ-USP website.

\section{Results and Discussion}

In the present experiment, the observations showed that there was a significant response of seedlings quality in different doses of sewage sludge. Thus, the germination of Brazilian 
pepper, Seven shells, Erythrina, False brazil wood and Guava was monitored in 30, 60 and 100 days, as shown in Figures $1 \& 2$.

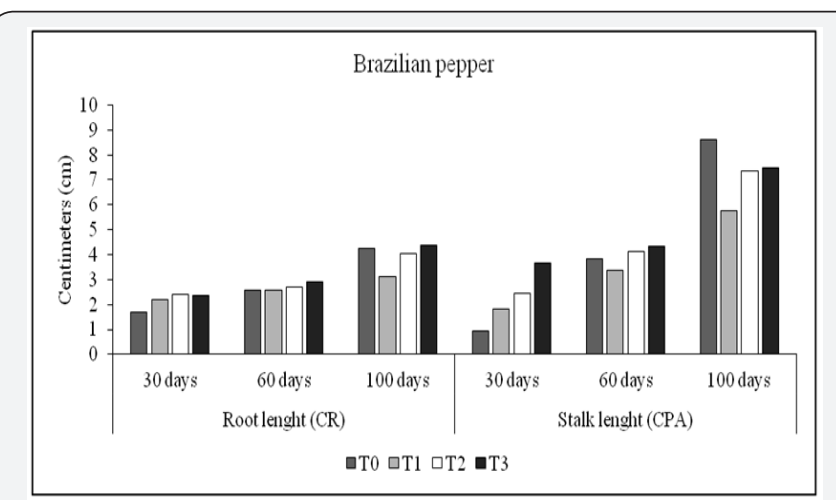

Figure 1: CR and CPA measurements of Brazilian pepper species at 30,60 and 100 days.

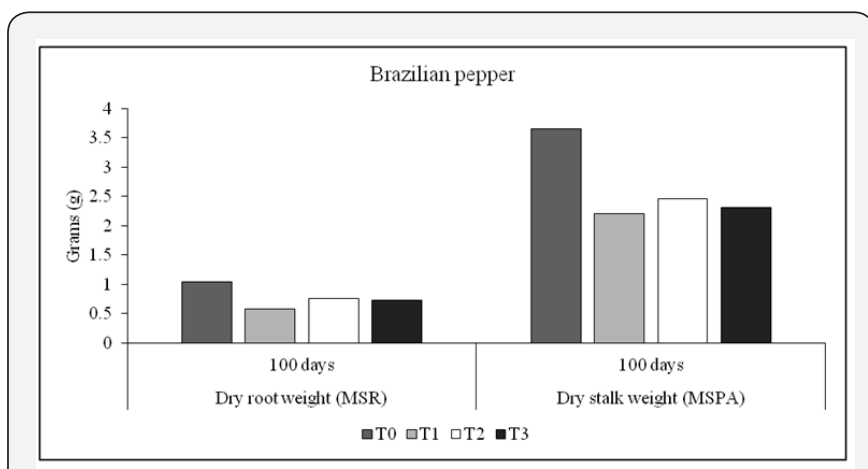

Figure 2: Measurements of MSR and MSPA of Brazilian pepper species in 100 days.

Through the monitoring of the Brazilian pepper, the germination occurred in 10 days after sowing. In general, the seedlings showed good germination during the whole follow-up process. For this species, the results of Figure 1 show that T3 has higher values than the other treatments, both in root length and stalk length (CR and CPA). In 100 days, T0 and T3 presented statistically equal values in the root length, with respectively $4,2 \mathrm{a}$ and 4,3a centimeters. By the general average, the T3 treatment presented better results in CR and CPA, followed by T2, T0 and T1. For stalk and root dry weight (MSR and MSPA), the results were relevant at T0 as observed in Figure 2, with 1.05a grams for root dry weight and 3.65a grams for dry stalk weight. By the general average, $\mathrm{T} 0$ presented as better treatment, followed by T2, T3 and T1. Compared with the results obtained by Trigueiro \& Guerrini [10], their phytometric parameters were like this study. Furthermore, they add that larger amounts of sewage sludge provided lower growth in height and diameter of the lap, which may justify the 100-day follow-up in the length of the aerial part (CPA), where the T0 treatment was highlighted with 8,6 centimeters against $\mathrm{T} 3$ which showed $7.4 \mathrm{~b}$ centimeters. Figures $3 \& 4$ show the results of the tests obtained with Erythrin.
For the Erythrin species, the seeds underwent scarification to break dormancy. The first signs of germination developed on the seventh day of planting. It is possible to affirm that the scarification aided in the faster germinative process of the species. The T3 test values observed in Figure 3 show better performance of CR and CPA at 30,60 and 100 days, followed by T2, T1 and T0. For stalk and root dry weight (MSPA and MSR), in agreement with Figure 4, higher results were also observed in T3, followed by T2, T1 and T0. After the 30-day period, the Erythrina seedlings were transplanted into pots for better germination of the plant and monitored in the mini greenhouse. Figures $5 \& 6$ show the results of the tests with Guava. For the species Guava, Singh \& Son [11] mentioned that the seeds have a tegument impermeable to water, presenting a low germination. Seed germination occurred after 20 days of planting. Analyzing the results of the species, in Figures $5 \& 6$, T1 obtained the best results in all parameters and in all periods, followed by T0, T2 and T3. According to Caetano et al. [12], the effect of sewage sludge doses on guava productivity didn't differ by $5 \%$ from manure and chemical fertilization. Figure $7 \& 8$ show the results of the tests performed with seven shells.

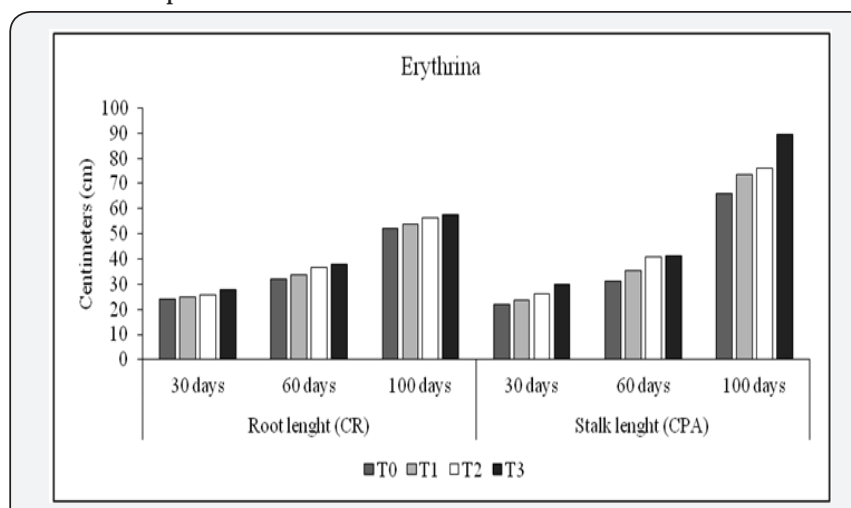

Figure 3: $\mathrm{CR}$ and CPA measurements of Erythrina species at 30,60 and 100 days.

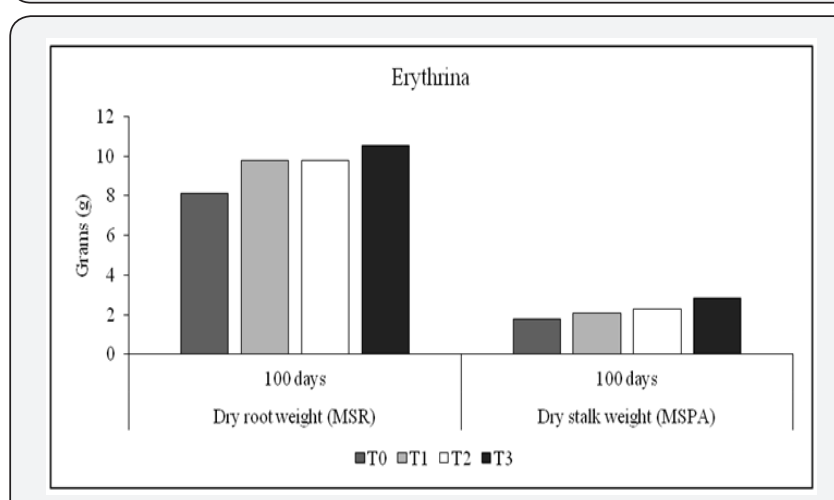

Figure 4: MSR and MSPA measurements of Erythrina species in 100 days. 


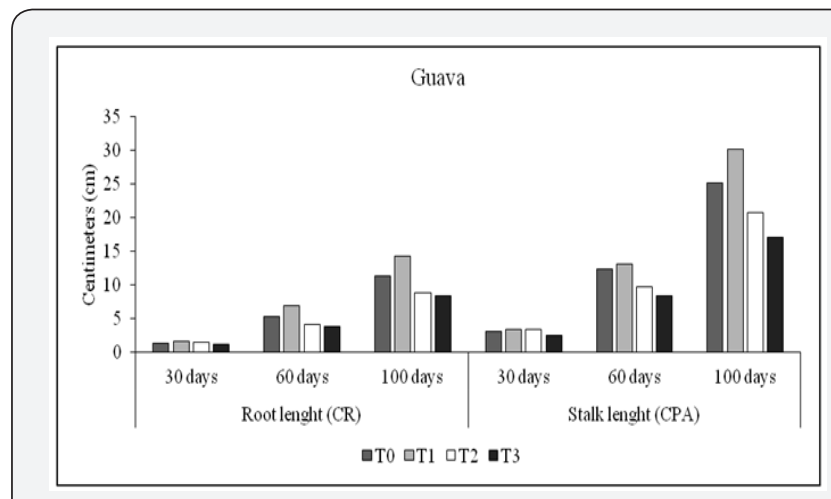

Figure 5: CR and CPA measures of Guava species at 30, 60 and 100 days.

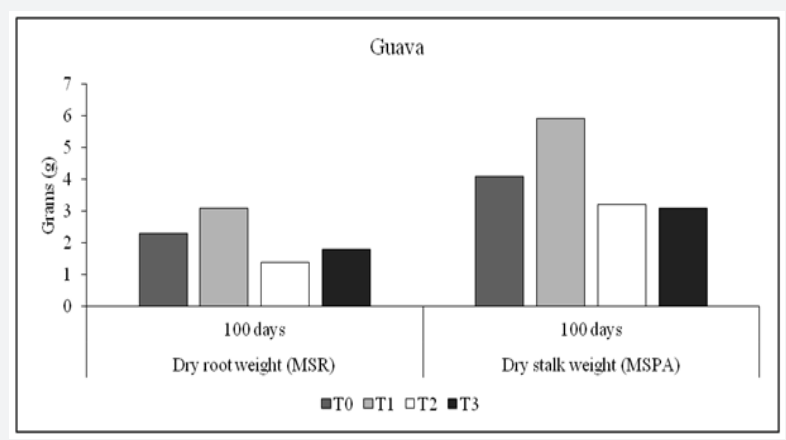

Figure 6: Measures of MSR and MSPA of Guava species in 100 days.

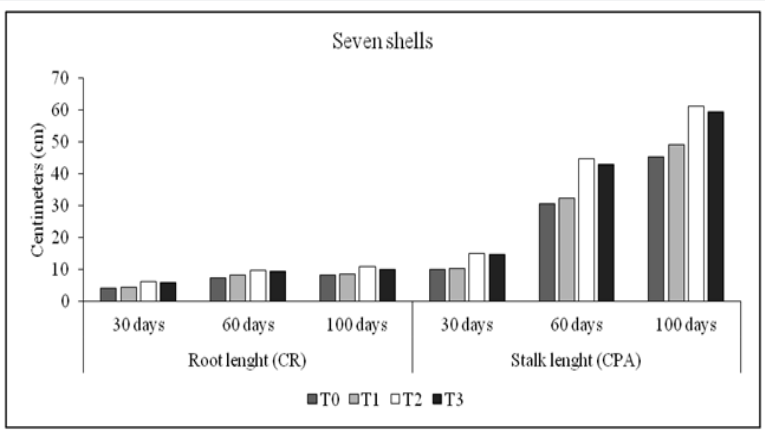

Figure 7: CR and CPA measurements of Seven shells species at 30,60 and 100 days.

Seven shells showed that during the germination process, the effect of scarification on the seeds was rapid, even though it was classified as secondary with rapid growth. The results presented in Figure 7 show that $\mathrm{T} 2$ obtained better performance in CR and CPA, followed by T3, T1 and T0. For MSR and MSPA, according to Figure 8, significant results were also observed in T2 and T3. In MSPA, results were obtained without statistical difference in T3 and T2, respectively with 19.76a and 19.09ab grams and in MSR there were differences between $\mathrm{T} 2$ and $\mathrm{T} 3$, with $2.43 \mathrm{a}$ and $2.11 \mathrm{~b}$ grams. After the period of 30 days, seedlings of Seven shells were transplanted into pots for better germinative development of the plant and accompanied in the mini greenhouse. Figures $9 \& 10$ show the results of the tests with False brazilwood.

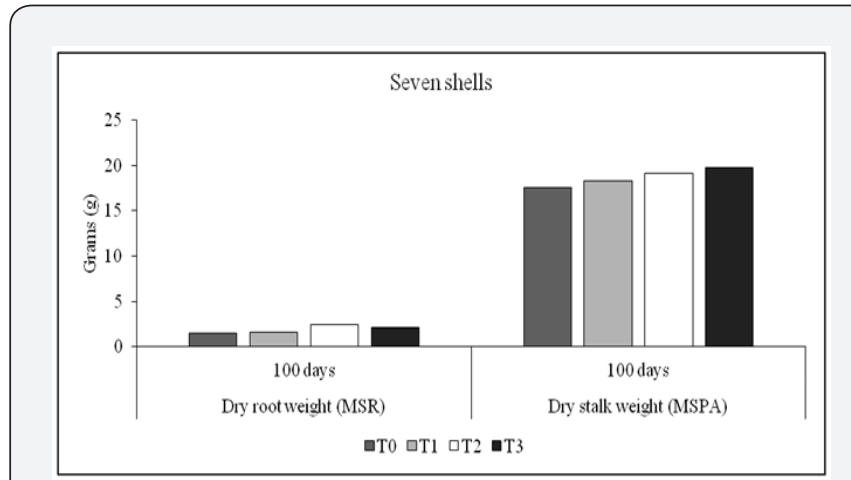

Figure 8: Measurements of MSR and MSPA of Seven shells species in 100 days.

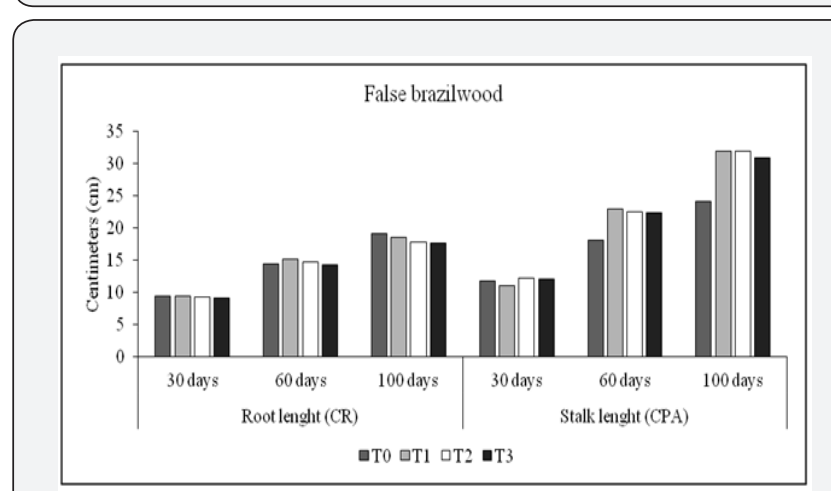

Figure 9: $\mathrm{CR}$ and CPA measurements of False brazil wood species at 30,60 and 100 days.

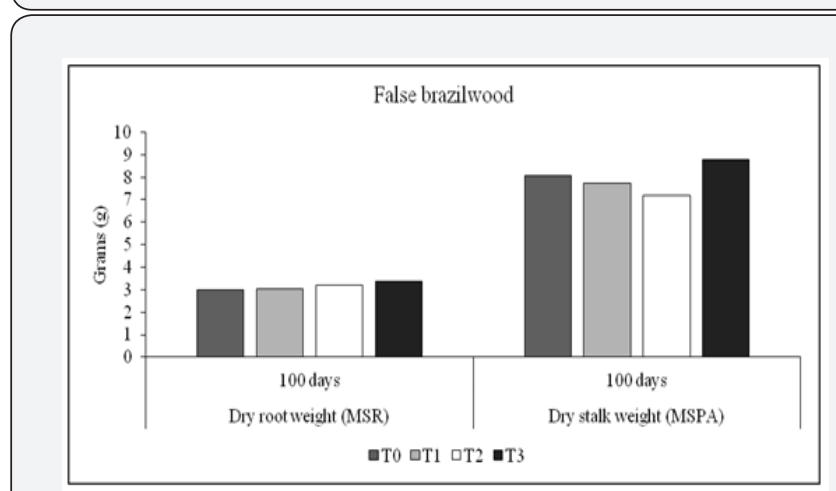

Figure 10: Measurements of MSR and MSPA of False brazil wood species in 100 days.

For the species False brazil wood, after breaking of dormancy by scarification, seed germination started from 12 days. After the averages analyzed among the treatments, as shown in Figure 9, T0 presented higher CR in relation to the other treatments, with 19.1 centimeters in 100 days, but T1 was statistically equal with the result of $18.51 \mathrm{ab}$ centimeters. In the general analysis of root length averages, T1 and T0 were statistically the same. In CPA, T1 presented the best result by analyzing the means in Figure 9, with 31.9 a centimeters, followed by T2 with 31 . 8a centimeters in 100 follow-up days. In the general analysis of stalk length, $\mathrm{T} 2$ and T1 are statistically the same. For the stalk and root dry weight (MSPA and MSR), higher results were observed in T3, according to Figure 10. The relation between the dry weight of 
the root and stalk, there was no significant difference between the different substrates.

Thus, each species obtained its peculiarity in the development of the phytometric parameters. Brazilian pepper obtained significant results in T0 $(100 \%$ substrate $)$. This confirms studies of Brazilian pepper in the use of sludge as a substrate. For the Seven shells species, the best treatment was T2 (40\% sludge $+60 \%$ substrate). For Erythrina, the best treatment was assigned to T3 (60\% sludge $+40 \%$ substrate) and we could also consider that there was a good performance through T2 $(40 \%$ sludge $+60 \%$ substrate). After observing the results obtained in False brazil wood, it is possible to conclude that the species obtained phytometric parameters with little variation of growth, and can be said that the species responds positively to any of the treatments submitted to this experiment. Finally, Guava presented significant results in the development of T1 $20 \%$ sludge $+80 \%$ substrate) where the seedling adapted to low fertilization, since its fertilization requirement is higher at the moment before fruit production.

\section{Conclusion}

The use of sewage sludge in the production of forest seedlings, in the composition of substrates, is a viable alternative for the final disposal of this residue. In addition, the selection of the species (Brazilian pepper, Guava, False brazil wood, Erythrina and Seven shells) will be adequate to offer diversity in the reforestation in the Paraiba Valley Ecological Corridor.

\section{References}

1. Pires AMM (2006) Uso agrícola do lodo de esgoto: Aspectos Legais. Embrapa Meio Ambiente, Jaguariúna, Brazil, p. 4.

2. Moraes Neto S, Abreu JR CH, Muraoka T (2006) Uso de biossólido em plantios florestais. Embrapa Cerrados, Planaltina 202: 1-16.
3. Abreu Júnior CH, Enedi AB, Takashi M, de Castro JK (2005) Uso agrícola de resíduos orgânicos potencialmente poluentes: propriedades químicas do solo e produção vegetal. Tópicos em Ciência do Solo Viçosa 4: 391-470.

4. Bettiol W, Camargo OA (2006) Lodo de esgoto: impactos ambientais na agricultura. Embrapa Meio Ambiente, Jaguariúna, Brazil, pp. 349.

5. Faria LC (2000) Fertilização de povoamentos de eucalipto com biossólido da ETE de Barueri, SP: demanda potencial e nível mínimo de resposta. Dissertação (Mestrado em Recursos Florestais) - Escola Superior de Agricultura Luiz de Queiroz, Universidade de São Paulo, Piracicaba, Brazil, p. 85.

6. Cunha AO, de Andrade LA, Alcântara Bruno RL, Lopes da Silva JA, de Souza VC (2005) Efeitos de substratos e das dimensões dos recipientes na qualidade das mudas de Tabebuia impetiginosa (Mart Ex DC) Standl. Revista Árvore, Viçosa 29(4): 507-516.

7. Saideles FLF (2009) Casca de arroz carbonizada como substrato para produção de mudas de tamboril-da-mata e garapeira. Revista Ciências Agrárias Londrina 30(4 Suppl): 1186.

8. Fernandes F, Andraus S, Andreoli CV, Rocha Pinto B, Janiliete Chemin B, et al. (1996) Eficiência dos processos de desinfecção do lodo da ETEBelém com vista a seu uso agrícola. Sanare Curitiba 5(5): 46-58.

9. Bortolini J (2014) Produção de mudas de espécies arbóreas nativas para a recuperação de áreas degradadas utilizando cama de aviário e lodo de esgoto. 2014. 44 f. Trabalho de Conclusão de Curso (Graduação) - Universidade Tecnológica Federal do Paraná, Francisco Beltrão, Brazil, p.1-44.

10. Trigueiro RM, Guerrini IA (2014) Utilização de lodo de esgoto na produção de mudas de aroeira-pimenteira. Revista Árvore 38(4): 657-665.

11. Singh S, Son SL (1974) Effect of water and acid soaking periods seeds germination in guava. Punjab Agricultural Journal 14: 122-124.

12. Caetano ICS, Costa N, Costa FS (2009) Utilização do lodo de estação de tratamento de esgoto para adubação da goiabeira. In: Congresso Brasileiro de Resíduos Orgânicos. Vitória, Brazil.

\section{Your next submission with Juniper Publishers} will reach you the below assets

- Quality Editorial service

- Swift Peer Review

- Reprints availability

- E-prints Service

- Manuscript Podcast for convenient understanding

- Global attainment for your research

- Manuscript accessibility in different formats

( Pdf, E-pub, Full Text, Audio)

- Unceasing customer service

Track the below URL for one-step submission https://juniperpublishers.com/online-submission.php 